\title{
Comparing Historical Cinema Cultures: The Case of the British West Indies, 1900-1945
}

\begin{abstract}
This essay evaluates some of the challenges and opportunities posed by comparative history of cinema-going by looking at the history of one understudied world region, Great Britain's Caribbean colonies. It concludes with a discussion of potential future comparative cinema-going histories involving these territories.
\end{abstract}

\section{Keywords}

cinema; Caribbean; Jamaica; Trinidad; movies

Scholarship associated with the 'New Cinema History' has proliferated over the past twenty years. According to a recent literature review, this growing field is characterised by attention to 'specific local practices of historical cinema culture' and is focused on 'film exhibition and audience experiences in particular cities, neighbourhoods, or venues. ${ }^{1}$ As a critical mass of studies has emerged, several scholars have called for a comparative approach to the history of spectatorship and exhibition. ${ }^{2}$ Comparative studies have the potential to illuminate broad trends and isolate key factors that inform local cinema cultures. ${ }^{3}$ Biltereyst, Van Oort and Meers have provided a model of this kind of scholarship in their study of cinemagoing in Antwerp and Rotterdam. ${ }^{4}$ Their work has demonstrated how the comparative method can highlight cultural and economic factors seemingly unrelated to cinema that nevertheless shape access to and engagement with, moviegoing. But while the handful of comparative projects have highlighted the value of this approach, they have also demonstrated its limitations. One challenge in conducting comparative studies is the uneven quantity and quality of data. Another is the relative bias of the field towards cinematic experiences in North America and Europe. This essay evaluates some of the challenges and opportunities posed by comparative history of cinemagoing by looking at the history of one understudied world region, Great Britain's Caribbean colonies. 
The British West Indies (BWI) included all of the colonies and dependent territories ruled by Great Britain in the Caribbean at the dawn of the cinema age. ${ }^{5}$ The populations of these territories consisted for the most part of Afro-Caribbean descendants of freed slaves. Each territory had a tiny commercial and landowning class of self-identified British expatriates and settlers. Two territories - Trinidad and Guiana - had large South Asian populations, the legacy of indentured servitude which had brought people from the Indian sub-continent throughout the British empire in the late nineteenth century. The economies were all based on the export of key commodities, such as tropical fruit from Jamaica, sugar from Barbados, minerals and timber from Guiana, and petroleum and asphalt from Trinidad. Each territory was dominated by a major coastal city which absorbed resources from across the colony and exported them abroad. It was in key ports such as Port-of-Spain, Trinidad, Kingston, Jamaica, and Bridgetown Barbados, that most commercial goods entered the colonies and most elites lived. On the eve of the First World War the shadow of the United States loomed over the region, as armed American intervention in neighbouring countries had been becoming increasingly common after America's war with Spain in 1898. And after 1918 Hollywood was only one of many American industries that was supplanting Great Britain as a source of imports.

This essay explores the history of cinemagoing in these territories up to the end of Britain's Caribbean empire in the early 1960s, focusing on those aspects of the story that made cinemagoing in the BWI distinctive. It argues that local conditions specific to the BWI limited access to movies for the masses before the mid-1930s. The key factors inhibiting expansion included a rigidly structured import/export economy which funnelled all commerce through a handful of key port cities, and a business climate in which entrepreneurs could gain social capital by marketing to European elites at the expense of the masses. This environment served to centralise the cinema industry in these territories to the point that by 1930 two men controlled the access to motion pictures of approximately two million people. But the emergence of a new class of local entrepreneurs, encouraged by Hollywood studios eager to pry open closed markets, had begun to stimulate cinemagoing by the early 1930s. The entry of the American military into the region after 1940 further helped sweep away these constraints, and ushered in an era in which the British West Indies became one of the most cinema-literate regions of the developing world. The essay closes with a discussion of the opportunities and challenges for future comparative cinema studies involving the BWI.

Examining the British West Indian colonies collectively allows for the identification of transnational networks in the cinema business that a national framework might obscure. This is 


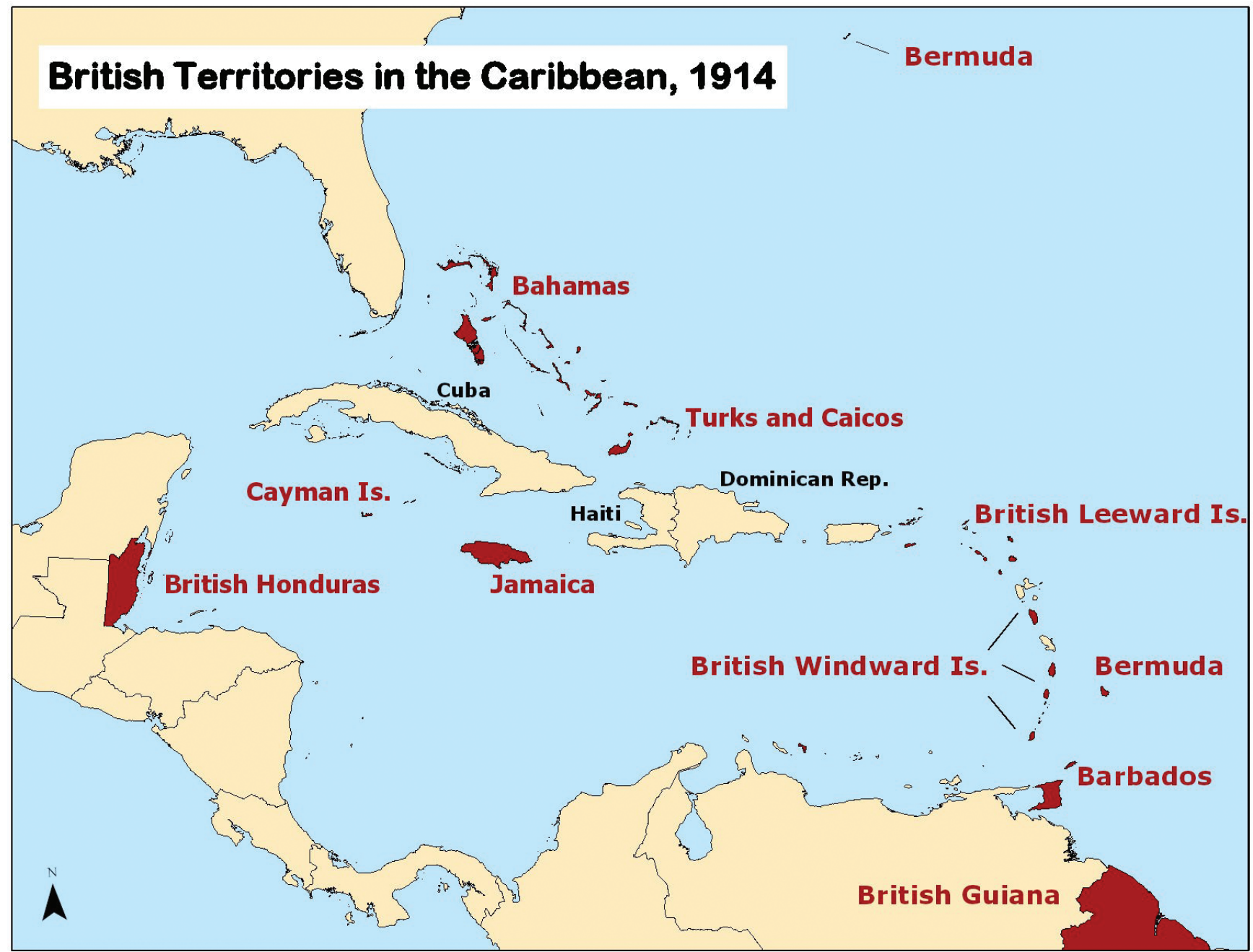

Figure 1. Map by the author.

particularly relevant in the Caribbean, where local cinema entrepreneurs crossed a variety of colonial and national boundaries. The focus on the British West Indies reveals how multi-ethnic entrepreneurs created a uniquely creole cinema business, continually volleying among American, British, Commonwealth, and regional connections. A comparative approach brings this hybrid transnational character of cinema in the Caribbean into focus. This study employs the local moviegoing lens of New Cinema History, focused on specific cities, but comparatively builds a story of regional interconnections that traversed national, colonial, and linguistic boundaries. It is based on an array of archival and published sources. Like much of the scholarship associated with the New Cinema History, it uses the press to reconstruct the expansion of movies and the movie business throughout 
the West Indies. While some of the newspapers used have been digitally archived, many were only available through microfilm or in their original copies held in national libraries. It also utilises archival materials that have been acquired through travel to institutions in Barbados, Trinidad, Jamaica, and the United Kingdom. And much of the biographical information regarding the entrepreneurs who created the Caribbean cinema business has been gleaned from cinema journals, colonial newspapers, and published memoirs of employees working in the cinema industry.

Before the First World War cinemagoing in the region was characterised by an openness of borders that encouraged entrepreneurs to travel freely across international borders with their itinerant shows. The first generation of travelling cinemas came largely from North America, and visited the major urban areas of the Anglophone colonies and the Hispanophone republics. The experiences of the Pan-American Electric Carnival, a road show run by the Canadian brothers E.L. and G.H. Ireland, provides a useful example of this early cinema economy. They began touring the American mid-western and southern states in the late nineteenth century, and ventured into the Caribbean in 1903. ${ }^{6}$ Their first recorded show in the British West Indies was in January of that year in Kingston Jamaica. While this was not the island's first show ${ }^{7}$, they became the most well-known cinema outfit in Jamaica, making several return visits between 1903 and 1908. They established a local following that was unrivalled by the handful of other travelling shows that visited in the early era.

The Ireland brothers carried a small collection of films which limited the amount of time they could profitably stay in any location. They relied on local connections to find venues and sell tickets for their shows. In Jamaica they established a relationship with Joshua Sollas, a local merchant and part-time theatre manager. Sollas booked the Ireland Brothers into the new Theatre Royal for their first visit in 1903 and sold tickets at his family's stationary store. The brothers also advertised in the island's main paper, The Gleaner , and received a good deal of free press in return. The Ireland Bros. made several trips to Trinidad as well. For their first visit in 1903 they took out an entire page ad in the local paper. While they visited these major cities of the BWI frequently, their travels took them to bordering countries as well. ${ }^{8}$ Indeed it was during a trip to Ecuador in 1907 that the elder of the brothers died of Yellow Fever.

The Ireland bros. was one of a handful of shows that crisscrossed the Caribbean before the First World War. But by 1910 the age of the itinerant cinema was beginning to give way to the establishment of permanent venues in many of the major cities of the BWI. In 1911 the first permanent cinema was established in the capital of Port-of-Spain in Trinidad. Advertisements for the 
London Electric Theatre assured audiences that this would not be yet another itinerant theatre by announcing 'We have come to stay.' The following year the first permanent cinema was established in the largest of the territories of the BWI, Jamaica. This was the Ward Theatre, built by an island philanthropist and owned by the city of Kingston. The manager was Joshua Sollas, the merchant who had served as the patron for the Ireland brothers during their several trips to Jamaica. Though it was

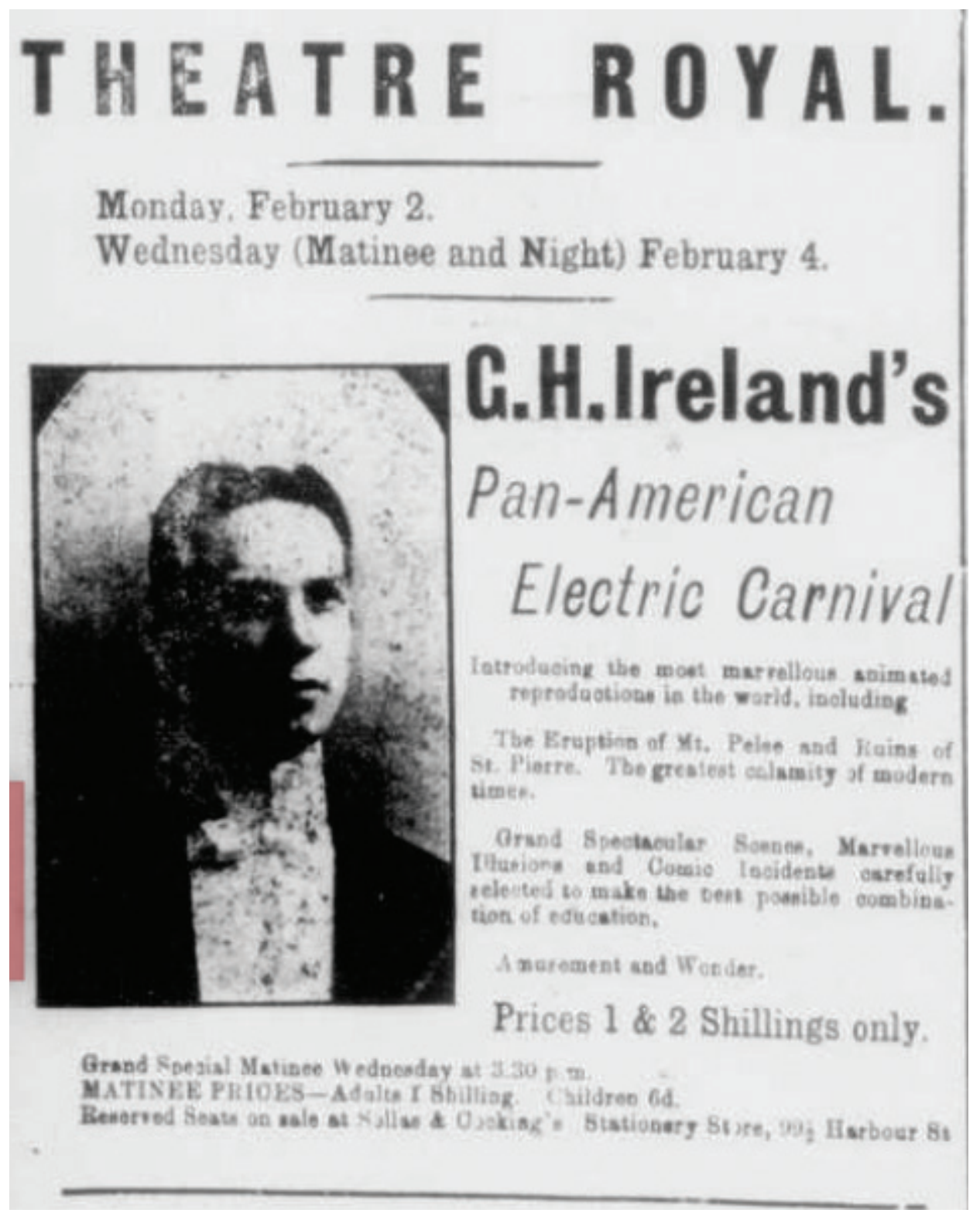

Figure 2. Advertisement in the Jamaica Gleaner for the Ireland Bros. cinema road show. The Ireland brothers visited several of the territories of the British West Indies shortly after the turn of the century. 
intended as a place for live performance, Sollas began booking cinema shows into the theatre almost immediately upon its opening. Not long thereafter several locally grown cinema shows cropped up which would rent out the Ward on occasion.

During 1913 local papers in Jamaica reported on several schemes to build permanent movie theatres. The first of these was the Pictorium, an English/Jamaican partnership that promised to build a brand new state of the art theatre in Kingston. This was advertised aggressively in the Island's press in spring and summer of 1913 before it mysteriously disappeared, with the theatre never being built. A second was from an American who arrived in spring of 1913 with plans to rent out the Ward theatre on a long-term basis to use it exclusively to show movies. This was Alfred James Roser, a colourful character whom the Jamaican press would dub 'our genial Barnum'. ${ }^{10}$ Roser had begun working in show business on Coney Island in 1904 and by 1908 had established his own movie houses in

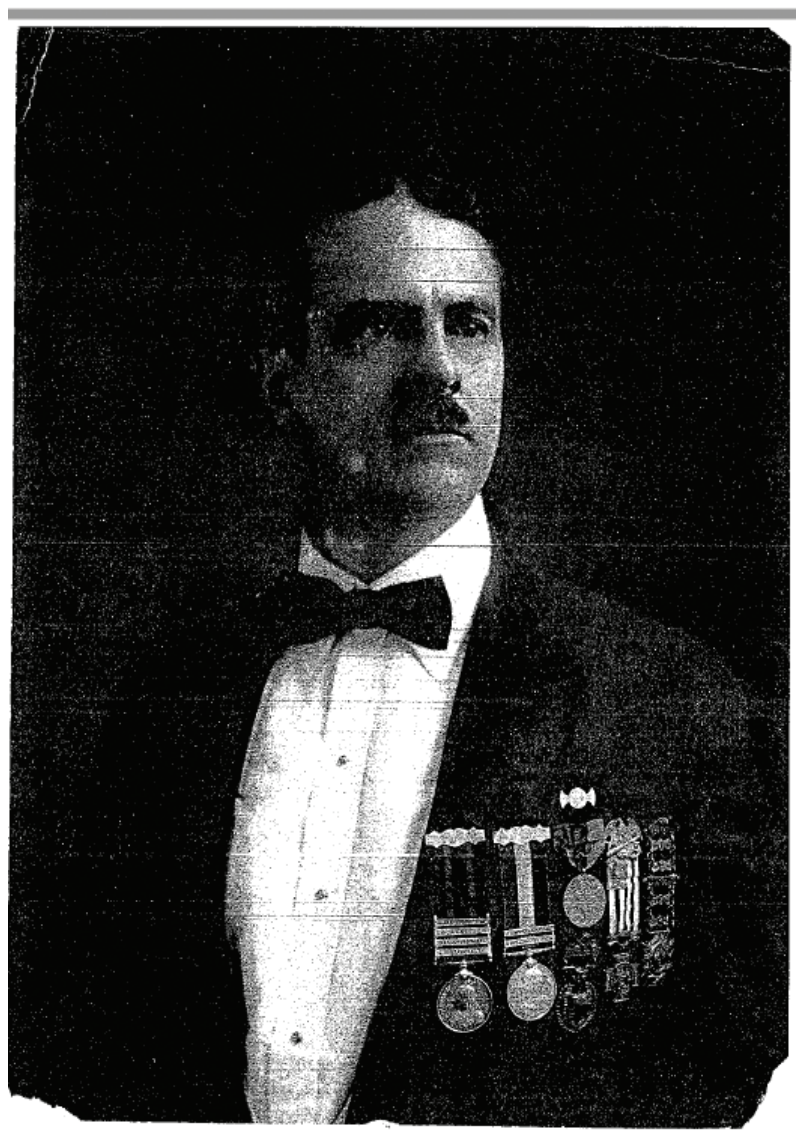

Figure 3. Alfred James Roser, an American cinema entrepreneur who established the 'Rose Garden' theatre in Kingston shortly before the First World War. Image courtesy of the Roser family. 
Brooklyn and Westchester County, New York. There he faced stiff competition during the nickelodeon era, and in 1913 he sold his cinemas and immigrated to Jamaica. He appears to have arrived in town with no local connections, but with several films in hand.

The city of Kingston rejected Roser's request to rent the Ward theatre on a permanent basis. Therefore he purchased a plot of land in town where he built his own theatre, The Rose Garden. By all accounts this was a well-capitalised complex that booked travelling entertainment as well as cinema shows, and included an amusement park. Roser kept his theatre supplied with new films by travelling frequently to New York to make purchases. This meant that virtually all of the films screened at this early venue were American. This left him vulnerable to critics who sought to disparage his business as being 'unpatriotic', and between 1913 and 1915 he was the target of repeated attacks in the island's press.

The success of Roser's theatre invited competition. His chief rival was Audley Morais, a teenage clerk in the employ of the wealthy DeMercado family who persuaded associates of his boss to invest in his moving picture theatre in late 1913. Morais and his investors - all from the island's established Jewish community - began a trade war with Roser which generated a good deal of negative publicity on both sides, civil law suits, a criminal prosecution, and a suspicious fire which destroyed the Rose Garden. Roser was ultimately hounded off the island in 1915, and embarked on a career running an itinerant cinema in some of the more remote corners of the Caribbean and Latin America. From Jamaica he took his films to Cuba, where he soon discovered that that island already had many more theatres than Jamaica. He left Cuba and spent much of the next decade touring in places like Haiti, Venezuela, and the tinier islands of the West Indies with few theatres. As the cinema spread rapidly throughout the Caribbean during the later 1910s and early 1920s Roser found himself in increasingly remote regions, until, like the Ireland Bros. before him, he threw in the towel on his road show and returned to New York for good in 1923.

Roser's career is instructive for two reasons. His success in establishing the Rose Garden demonstrated that Jamaicans were hungry for cinema entertainment, and could support multiple theatres. But his failure to survive in the tough world of Jamaican business emphasised the value of local connections in the cinema trade. One of the ironies of Roser's career was that he attempted to trade on his status as a British officer and gentleman to give his cinema business status, thereby giving his rivals the opportunity to publicly criticise him for unpatriotically showing American movies. Yet Roser appears to have been born into a Jewish family in America, a social position which 


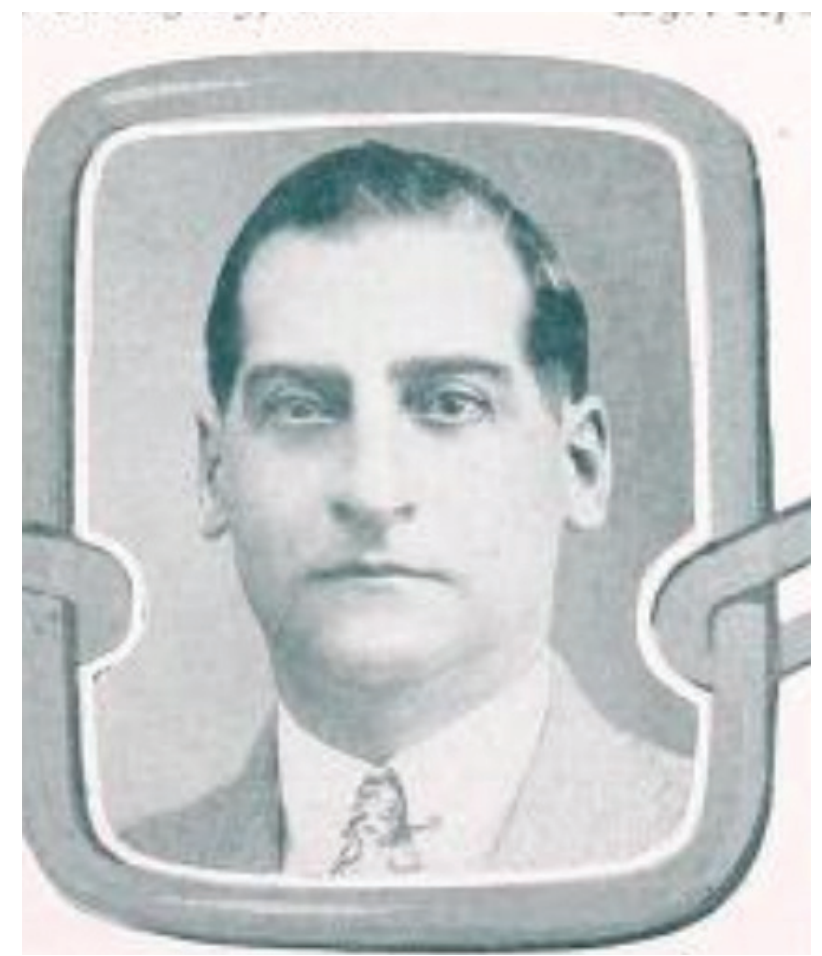

Figure 4. Audley Morais, founder of the Palace Amusement Company, Kingston Jamaica, which has been in business on the island since 1921. Image from 'Paramount Around the World' advertisement, July 1, 1930.

under different circumstances might have helped him find common ground with the local merchant community in Jamaica, who were almost all members of long established Jamaican-Jewish families. ${ }^{11}$

Another of Roser's rivals in Jamaica was George Ivan Rosenthal, a fellow American who had gone into business with Audley Morais. Rosenthal would eventually establish successful retail chains in both the British West Indies and the Union of South Africa, even though he arrived in both places with no connections. He was born in New York in 1885, the son of Jewish immigrants from Western Russia. As a young man he found work on the Panama Canal, where he was impressed with the demand for public leisure among the large expatriate work force. ${ }^{12}$ By 1913 he had scraped together enough capital to purchase several films, which he brought to Jamaica. Rosenthal started a business called the British Colonial Film Exchange, and began advertising the rental of his films in the pages of the island's main paper. He did not show them in Kingston, where they would have competed with Morais and his partners, but in provincial towns. ${ }^{13}$ Like Roser, he travelled to New York periodically to acquire new films, and used his contacts there to also manage visiting vaudeville shows at a venue in Kingston. ${ }^{14}$ In 1915 Rosenthal's film vault burned, destroying his entire stock. ${ }^{15}$ Reports of the fire 
indicate that he had hundreds of films in his collection, and that the business was insured. With nothing to rent, but with the backing of his partners in Jamaica, he immigrated to Trinidad to rebuild his distribution business.

Upon arriving in Trinidad Rosenthal found that the island already had several cinemas operating in the capital of Port-of-Spain. The first cinema had been opened by local businessman Reginald Davis in 1911. Davis’ partner was Lionel 'Lanky’ Belasco, a musician from a Sephardic Jewish family from Venezuela, who would go on to become a calypso star in North America. In 1916 Rosenthal arrived from Jamaica and began renting out space in a theatre in town to show films. He dubbed his new theatre the City. ${ }^{16}$ Over the next two years several new theatres appeared in the capital, including the Olympic, which was started by Belasco in 1917, and could accommodate 600 patrons. ${ }^{17}$ By the war's end the Trinidad Argus noted that despite the wartime privation the citizens of Port-of-Spain continued spending money on the cinemas, which 'are springing up everywhere'. ${ }^{18}$

Rosenthal and Davis attempted to consolidate their businesses, but ended up in court in an argument over assets. ${ }^{19}$ Rosenthal instead brought a merchant from British Guiana named William Humphrey into his company. Humphrey was the son of an English diamond merchant from Georgetown, Guiana. As a young man he had run a series of small businesses, including a dairy farm and a carriage hire service, before he became interested in the movies. In 1913 he opened Guiana's first movie house, the Olympic. His big break came in 1917, when he travelled to America and acquired his own copy of the film Daughter of the Gods (US 1916). Humphrey's road show of the film received newspaper coverage across the region, particularly among envious readers in Jamaica. With Humphrey on board, by 1922 the British Colonial Film Exchange had a monopoly on cinemas in Trinidad and Guiana, and began extending their circuit to neighbouring colonies. In 1922 the company financed and built the luxurious Empire cinema on the island of Barbados, which still stands in the capital of Bridgetown. The building of the Empire reflected their business strategy, which sought to manage a handful of expensive venues in central locations that catered to the region's elite. Besides the Empire in Barbados, the company constructed several other state of the art facilities, including the Empire in Port of Spain Trinidad, which was described in 1925 as having cost $\$ 100,000$, and which was described as the premier cinema house in the British West Indies. ${ }^{20}$

Rosenthal left the Caribbean for South Africa in 1924, and his partner Humphrey took sole control of their empire. By decade's end, the British Colonial Film Exchange built several new venues across the BWI, many with names calculated to appeal to an expatriate audience such as the Empire 
and the London. One can catch a glimpse of his attitude towards audiences in his native Guiana during a controversy that emerged involving his Olympic theatre in 1917. When a letter to the editor of the Daily Chronicle suggested that the theatre show films for free on Sundays, a spokesman for Humphrey complained 'if the show was free the whole house would be open to all classes, which would be very objectionable. ${ }^{21}$

In Jamaica, Morais' company, Palace Amusements, adopted a similar attitude towards marketing to the masses. As he explained in a 1922 interview he gave to the Exhibitor's trade review, 'in a land of 75,000, only 1,600 are potential movie patrons.' He went on to say of these elite patrons 'We get the people in the higher circle of society and since they are very much in the minority, that is what makes our percentage of moviegoers so small. ${ }^{22}$ Since the population of Jamaica was more than ten times this figure in the early 1920s, it appears that Morais only considered the public of Kingston as his potential audience. ${ }^{23}$ Regardless of his faulty math, he was clearly focused on selling cinema seats to the island's elite.

This did not go unnoticed by the public, or by potential rivals. His two cinema houses in Kingston, The Palace and The Movies were criticised in the press for not providing new or worthwhile pictures, and it was widely intimated that he passed off inexpensive and older prints to a public starved for entertainment. One well publicised example of this was the screening of the film Daughter of the Gods, which the Fox Company had filmed at enormous expense in Jamaica in 1915. The shooting had employed many people on the island and the local press had covered its production enthusiastically. It was released in New York in 1916, and was playing in neighbouring Guiana the following year. But the Jamaican public would have to wait until 1919, presumably because it was deemed too expensive to rent before that. Morais' approach to the cinema business differed from Humphrey's in that he demonstrated little interest in building sumptuous movie palaces. His strategy was rather to ruthlessly prevent any other cinema house from challenging his monopoly, thus obviating the need for improvement or expansion. ${ }^{24}$ Indeed, while Humphrey invested in sound technology early for his major theatres, some of Jamaica's theatres did not get sound until two years after it had come to Trinidad.

One of the ways in which Morais and Humphreys were able to monopolise the cinema trade was by controlling film imports. Before the First World War, most movies screened in the Caribbean were brought there by businessmen like Roser and Rosenthal who frequently travelled to New York to acquire new films. As the American cinema industry seized control of global distribution during the 
war, the Palace Amusement Company and the British Colonial Film Exchange were able to channel imports from the U.S. through the cities of Port-of Spain, Trinidad, and Kingston, Jamaica, from where they would be shipped to small colonies and regional towns. This was in large part because of the economic geography of these small territories, which funnelled all trade through the port-capital of each colony. By 1930 this had given them a stranglehold on distribution throughout the British West Indies. Of the two companies, the British Colonial Film Exchange had a much greater reach. While the Palace company dominated the market in Jamaica, the most populous of the British territories, Humphrey's controlled the market in almost every other colony. According to a U.S. State Department report published in 1931, most cinemas across the BWI either were owned by the British Colonial Film Exchange, or were reliant on the company to supply them with films. Thus the only cinema on the tiny island of Antigua was 'owned by the Colonial Film Exchange at Port of Spain, Trinidad' as was the lone cinema on the island of Dominica. The 400-seat theatre on the island of St. Vincent 'is operated under control of the Colonial Film Exchange at Port of Spain. ${ }^{25}$ Though Clarke's cinema on the island of St. Lucia was owned by a local company, it is understood that it is operated under control of the Colonial Film Exchange at Port of Spain.' Indeed the only British territory in which neither the Palace nor the British Colonial Film Exchange ran the cinema industry was in the Bahamas. In this territory - less than 200 miles from the Florida coast - by 1930 the local industry was controlled by the American-based chain Wometco. The company's cinema chain in Florida included a number of 'coloured' theatres in African-American neighbourhoods. Given Wometco's business in America, it is unsurprising that in 1929 in Nassau, the largest city in the BWI outside of the Morais and Humphrey empires, there were three cinemas which according to a contemporary report 'cater to the native population'. ${ }^{26}$

As their monopolies tightened, both companies began to face prospective rivals who were eager to profit from the pent up demand for more cinema venues. Morais had faced his first challenge in 1919, when a group of Jamaican attorneys and businessmen created a public company to build a new theatre in Kingston called the Rialto. But allies of Morais filed suit to stop its construction, ostensibly on the grounds that it would create traffic and ruin the neighbourhood where it was to be built. ${ }^{27}$ Eventually the frustrated owners sold the building to Morais, who opened it in 1923, having apparently reconciled himself to its adverse effect on urban congestion. The following year he faced a challenge from what local papers referred to as a 'Chinese syndicate' headed by a young Jamaican businessman named Albert Chang. Morais could not stop the new theatre's construction and the 
Gaiety opened in 1924. The press predicted its opening would improve the overall quality of moviegoing in the city by creating competition with the Palace. Threatened by this new rival, Morais took the extreme step of inviting an American theatre chain from New Orleans, the Saenger company, to buy up the Gaiety for him, in exchange for selling them a minority share in the Palace company. Thus was another rival was absorbed into the Palace chain.

The British Colonial Film Exchange also found itself confronted with competitors in the late 1920s. In Trinidad and Guiana the initial challenges came from entrepreneurs who sought to exploit the pent up demand for entertainment in rural towns and villages. A key to their early success was the importation of films from India, which appealed to the large South Asian populations of Trinidad and Guiana. Humphrey discouraged the importation of Indian films and did not want them shown in his cinemas. ${ }^{28}$ However by the eve of the war these films were being shown regularly in small cinemas in the rural towns of Trinidad and Guiana. ${ }^{29}$

The initiative for these screenings came from several South Asian businessmen. Henry Teelucksingh was a merchant from the Trinidadian provincial town of Couva who built his first cinema there in 1916, and subsequently employed mobile film units that screened films throughout the countryside. During the early 1930s he worked for Humphreys, but quit to start his own rival company. Nur M. Gokool was another merchant who challenged the Humphreys' monopoly during the 1930s. He was the son of a wealthy Indian immigrant who had studied to become a physician in Britain before becoming enamoured with the cinema business. In 1932 he started The Globe cinema company and reached out directly to MGM for help in challenging the Humphrey's monopoly. MGM helped him finance a new theatre called the Metro in the capital ${ }^{30}$, but the following year Gokool broke with them and renamed his theatre the Globe. Shortly thereafter another Indian immigrant, Timothy Roodal, established a competing theatre the Roxy, in Port-of-Spain. Within five years Roodal had opened six theatres in rural areas to serve rural Indian audiences. All of these new companies catered to the poor Indian audiences that Humphreys had largely ignored.

In Jamaica, challenges to the Palace gained strength during the 1930s, as rivals there also looked to Hollywood for help in opening up the market. In August of 1937 an island businessman names B.M. Andrade made a deal with MGM to build a state of the art cinema in Kingston. ${ }^{31}$ The upscale Carib theatre would be the first building in the British West Indies to have air conditioning. As the manager of the Carib explained later, 'MGM realised that if their films were even to be shown in Jamaica either the price would have to be reduced or the theatre monopoly would have to be 


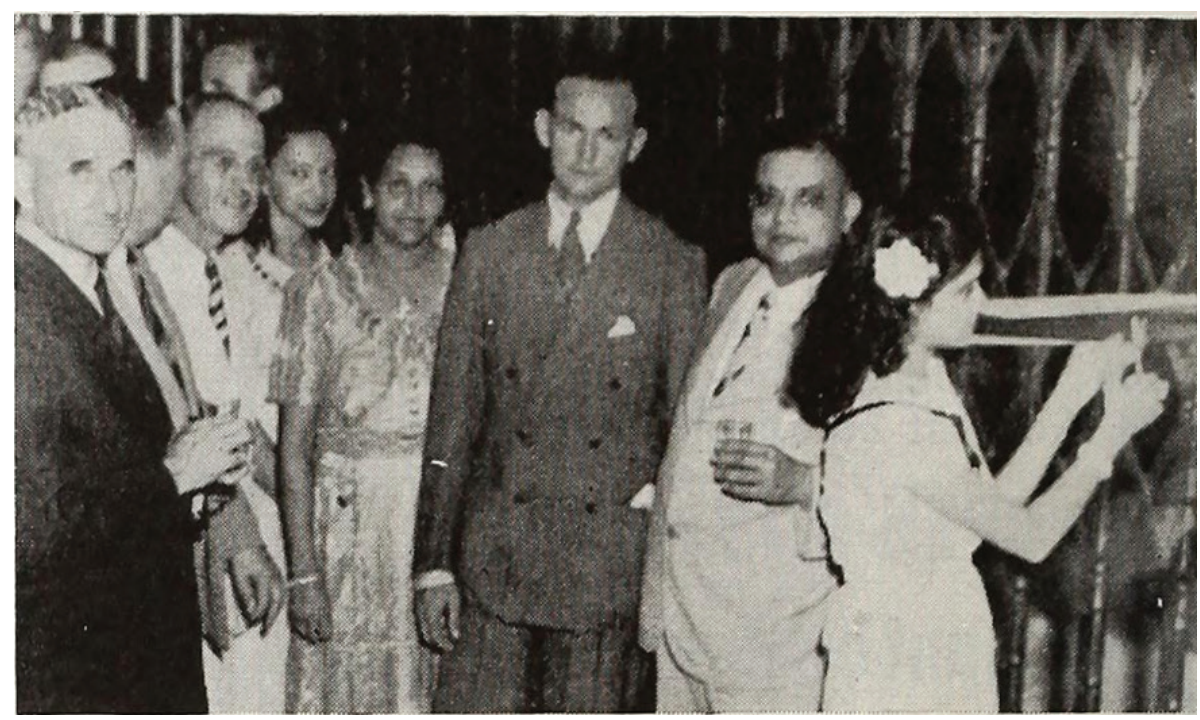

Figure 5. Trinidadian entrepreneur Henry Teelucksingh (centre) at the opening of the Astor Theatre, Port-of-Spain Trinidad, in 1947. Motion Picture Herald, September 13, 1947 p. 66.

broken. The MGM people decided upon the latter course.' Their partnership resulted in 'the building of a large luxury cinema in Kingston, which would get the exclusive rights to the exhibition of MGM and 20th Century Fox films. ${ }^{32}$ Morais was unable to stop its construction and when it opened its doors in 1938 he was facing his first serious rival since 1913. As the manager of the new Carib wrote in his memoir, MGM and 20th Century Fox films began to flow ... into Jamaica. But this did not come about without generating large amounts of bad blood on all sides.' Faced with competition for his best customers - the middle and upper classes of Kingston - Morais was once again forced to buy out a rival and Palace Amusements absorbed the Carib on the eve of the war. ${ }^{33}$

But soon thereafter another island merchant announced plans to open a new theatre in Spanish Town, the poor adjunct to the capital Kingston that the Palace Amusements company had neglected. ${ }^{34}$ By this point Morais was becoming exasperated with the challenges to his monopoly, and in an interview with The Gleaner he expressed his frustration with critics whom he accused of misunderstanding the market. 'Where is the patronage to come from?' he asked, while asserting that all of his theatres operated at less than half capacity. But his complaints had no effect and shortly after the war construction began on the Majestic in Spanish Town. ${ }^{35}$ Apparently there was a whispering campaign against the new theatre, as on the first anniversary of its opening The Gleaner commented on 'all the false rumours and wicked lies whispered about the Majestic by malicious 
persons who did not wish to see it succeed.' The paper gleefully noted that these efforts had 'failed to stem the tide of satisfied patrons who had beaten a path' to the Majestic. ${ }^{36}$ The paper went on to celebrate the new theatre as 'a place where high and low, rich and poor can find the best entertainment at the lowest prices and enjoy it under the most pleasing circumstances.' 37

As the 1930s progressed these cinema monopolies started to unravel. In Trinidad and Guiana, South Asian businessmen established humbler venues that catered to the poorer audiences that the Humphrey company eschewed. These small merchants fought a bitter business war with Humphrey throughout the decade, which resulted in one case in a rival going to prison for trying to burn down his flagship Empire theatre in Port of Spain. Despite the efforts of Humphreys and Morais to limit the market, by the eve of the war the cinema habit was catching on throughout the region. A British traveller in the Caribbean in 1938 found that

from one end of the archipelago to the other, from Jamaica to Trinidad, the lure of the cinema (...) was inescapable. It provided a relatively inexpensive activity for the masses, affording them a look at another world beyond the confines of the islands, and allowing them to submerge themselves in other adventures, albeit from a distance. ${ }^{38}$

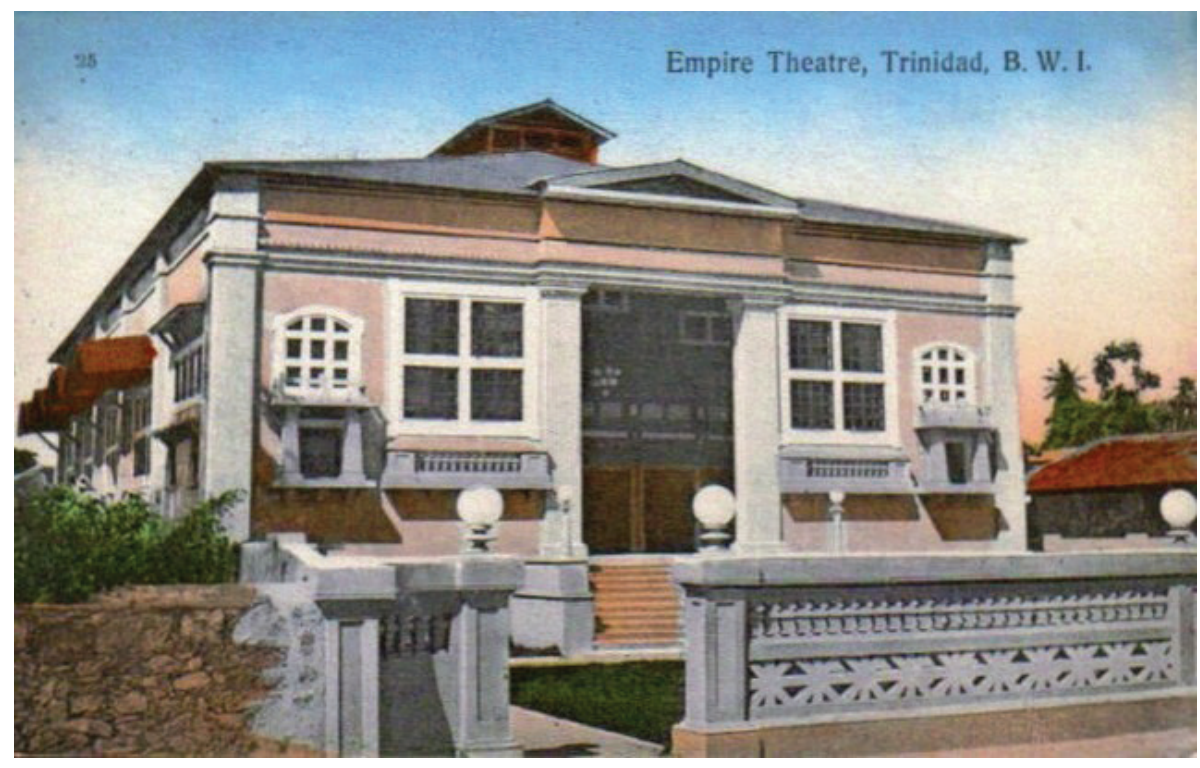

Figure 6. The Empire Theatre in Port-of-Spain Trinidad. The British Colonial Film Exchange named several of their cinemas 'The Empire'. The largest of these was in Bridgetown, Barbados, which is still standing. Source: www. cinematreasures.com 
The growing popularity of the movies in Jamaica was described in an editorial published early in the Second World War, which lauded film for providing the 'major entertainment fare for rich, poor, young and old. ${ }^{39}$ It was equally popular in Trinidad, where at the start of the war the capital Port of Spain, with a population of about 80,000 , supported nine theatres. ${ }^{40}$

The Second World War provided a significant boost to moviegoing across these territories, and dramatically expanded the demand for venues. This ultimately helped to end the already struggling monopolies of the pre-war era. One reason for the boom was the arrival of American troops, who followed in the wake of America's 'ships for bases' treaty with Great Britain. ${ }^{41}$ By the end of the war thousands of American soldiers had served in virtually all of the major territories of the Caribbean. ${ }^{42}$ The army and navy opened multiple theatres for serviceman on several islands, and flooded local economies with dollars. ${ }^{43}$ But the rising popularity of the cinema was also fed by the economic boom that affected the entire Caribbean, as the war created demand for commodities and labour in economies that had been largely moribund during the depression. This drew swarms of rural people to the cities, and put spending money in the pockets of new workers. Wartime exigencies curtailed investment in new movie theatres, and made it more difficult to import new films. But at war's end, the pent up demand spurred a rapid post-war boom. Humphrey had had enough by 1940, and sold his business to the Globe cinema company. In Jamaica Morais also grew tired of the growing competition and sold his theatres to the J. Arthur Rank company shortly after the end of the war. Thereafter, the cinema business grew throughout the BWI, to the point that by the time the territories became independent in the 1960s, their per capita number of cinema houses finally rivalled that of their Caribbean neighbours.

The evidence presented here demonstrates that in the British West Indies until the eve of the Second World War, the control of cinemas and film distribution was largely a monopoly of two individuals, who shared a commitment to a particular business strategy that worked against the mass dissemination of the medium. Why did these men pursue this approach? It was not because they were poor businessmen. Rather they were motivated by their shared aspiration to use these businesses to elevate their status within their respective colonial societies. And while growing the market might have been economically profitable, it would not have helped their standing in the eyes of the colonial elite. Throughout the early history of the cinema in the region - right up to the Second World War - there was strict censorship of films throughout the BWI and robust public debates regarding the pernicious effect of movies on the colonial masses. ${ }^{44}$ Both of these men had social pretensions which 
made them keenly sensitive to elite and official views of their cinema empires. On numerous occasions the British Colonial Film Exchange faced criticism from the colonial establishment about the effect of its cinemas on the pubic. For example in 1920, the Colonial Office received an extended complaint about the behaviour of audiences in Trinidad, which lamented the inability to racially segregate audiences to protect them from the bad effects of film. ${ }^{45}$ Later in the decade the police inspector of Guiana, a member of the territory's film censorship committee, wrote a scathing report about the behaviour of local audiences at Humphrey's theatres. It lamented 'the objectionable deportment of the audiences; Films barely tolerable in them-selves, being rendered far worse by the comments and lewd behaviour which they excited.' It concluded with a call to the management to established 'a moderate degree of silence and decorum. ${ }^{46}$ In this context, Humphrey had to balance the appeal of selling tickets against the costs of drawing the ire of colonial elites. Humphrey's was a product of the expatriate merchant family of Guiana, who had been hustling from a young age to establish a successful business in that colony. Eager to gain acceptance in the colonial society of Guiana (and later Trinidad, where he moved permanently as it increasingly became the centre of his cinema business) his goal appears to have been to use his successful business to enhance his social status. Indeed, unlike the merchants who challenged his monopoly, the cinema was his only business. This contrasts with his American partner Rosenthal who was more interested in turning a profit, and cashed in his business in the BWI in 1924 in order to fund his mass-market clothing business in South Africa. As head of the British Colonial Film Exchange Humphrey focused his resources on constructing high-end cinemas, and even made efforts to show British rather than American films to placate the preference of British elites, despite the clear preference of the masses for films from Hollywood. Humphrey sent his son to school in England, and the young man would return to launch a career in island politics. The family settled in a mansion in Trinidad which was one of the 'seven sisters' which are today historic landmarks. For Humphrey the profits of the countryside could be left to those entrepreneurs who were willing to chase small profits from a mass audience. These businesses would eclipse his as the market exploded.

In a similar vein, Audley Morais was a merchant who used the cinema business as a vehicle for social mobility. Like Humphrey, movies were his only business. Like Humphrey he came from relatively humble roots, having started out as a clerk in a Kingston dry goods store. Early in his career Morais saw his rival hounded off of the island in part because he was seen as too willing to put profit over the tastes of the Island's British elite, thus leaving him vulnerable to charges of being 
'unpatriotic'. During the 1920s, the cinema business had been targeted by numerous elite critics who warned that its growing popularity among the Jamaican masses was a threat to British rule. In this context, Morais had no interest in being seen as a purveyor of a mass medium. Instead he used his commercial success to set himself up as a pillar of Jamaican society, becoming a leader in the island's horse racing community, and dabbling in colonial politics. Thus his enthusiasm for making the cinema a mass medium was muted by his desire to be a purveyor of uncontroversial entertainment for elite audiences.

\section{Discussion}

There are several promising opportunities for comparative studies involving the BWI. The first would be a study of the contrasts between the cinemagoing histories of the different territories that made up the BWI. Though they shared a good deal in common, there are differences among the territories that could profitably be explored. The most apparent is the role of South Asian immigrants in giving Guiana and Trinidad their unique history with the movies. These states experienced the most dynamic and sustained growth in cinemagoing after the end of the Morais and Humphrey monopolies. According to a survey of cinemas in the empire conducted by the British Colonial Office, in 1928 Jamaica had fifteen cinemas, Trinidad seventeen, and Guiana six. ${ }^{47}$ Ten years later, despite having a much larger population, Jamaica still had the same number of theatres, but Trinidad and Guiana both now had 28. This trend continued throughout the post-war period until by 1998 , Trinidad, with half the population of Jamaica, had twice the number of cinemas. Anecdotal evidence suggests that it was growth among Indian communities in rural areas that accounted for the disparities that developed between Jamaica and these two other territories in the post-war era. If this were the case, then the significance of the consumption of Indian films among these diasporic communities in Trinidad and Guiana would be a fertile line of inquiry.

Another fruitful comparison would be to contrast the experiences of the people of the BWI with colonial subjects in other parts of the British Empire. My 2013 book emphasised the commonalities that colonial rule imposed on cinemagoing throughout the British Empire. Since its publication there have been several excellent works that have expanded our understanding of cinemagoing in a colonial context. This body of work on colonial cinemagoing illuminates several potential points of contrast between the BWI and other British territories. One factor that made the distribution of film 
in the BWI anomalous was the narrow channelling of films through key points of import that permitted Morais' Palace Amusement Company and Humphrey’s British Colonial Film Exchange to control distribution. Elsewhere in the empire distribution was characterised by a multiplicity of distribution points from where films entered colonies. This prevented individuals from exerting the kind of influence on distribution that characterised the history of the British West Indies. In Britain's Asian colonies for example there were many metropolitan areas that imported (and even produced) films for circulation. There were major companies that ran chains similar to the British Colonial Film Exchange. In the British South East Asian colonies it was Run Run Shaw's company which carved out a vast entertainment empire throughout the region during the 1930s, while in India the Madan company ran nearly 300 theatres by the mid-1920s. But these markets had room for a multitude of entrepreneurs, large and small, who ran their own cinema businesses. In a similar vein Laura Fair's recent work on Zanzibar has demonstrated the multiplicity of sources for films in that colony, and the diversity of the community of businessmen involved in the small-scale business of cinema exhibition and distribution. ${ }^{48}$

In many respects the territory whose cinema history was most similar to the BWI was South Africa, where all imported films entered through the city of Cape Town. In Britain's southern African colonies the control of the cinema fell into the hands of one organisation, the Schlesinger company, which controlled the distribution of films from the Cape to Kenya. Like the Palace and the British Colonial Film Exchange, this organisation targeted the affluent white community of the colony, and built grand picture palaces that surpassed the grandest constructions in the BWI. But the Schlesinger company worked assiduously to make cinema available to all who were willing to pay. And while cinema was not a truly mass medium before the Second World War, it had become a fixture for shows on mining compounds and in poor urban neighbourhoods before the end of the silent era. Also, as was the case for the vast majority of cinema-businesses throughout the empire, movies were just one of several lucrative industries that the Schlesinger organisation was invested in. Indeed, the movies were an industry that was almost literally thrust upon Schlesinger because of his success in insurance, commercial agriculture, and other ventures. Thus I.W. Schlesinger, the owner of the company, was not interested in cinema as a lever of personal status or social mobility. Though he was keenly concerned to keep on the right side of the segregationist governments of the time, his company sought profits where they could find them, and left no market ignored. Like the industry tycoons of the BWI, Schlesinger faced the growing competition of the American studios during the 
1930s, as well as well-funded internal competitors. As happened in Jamaica, Schlesinger was able to absorb these rivals through a combination of intimidation and investment during the 1930s, but by the war's end he had sold out to his competitors.

Finally, it would be illuminating to compare the cinemagoing history of the BWI with the experiences of neighbouring Caribbean states. This would shed light on the extent to which media flows in the region were shaped by political borders and/or cultural and linguistic affinities. It could also explain the dramatic disparities between the per capita numbers of cinema-houses in the BWI as compared to neighbouring states. Data published in the Film Daily Yearbook and in reports generated by American consular officials ${ }^{49}$, demonstrate these dramatic contrasts. In 1943 in Cuba there was one theatre per 11,137 people, in Panama the ratio was one per 11,184, and in Puerto Rico one per 13,000. In the Mexican province of Yucatan alone according to the 1923 census there were approximately sixty motion-picture venues in a province of 350,000 people, a ratio of one per 5,800. 50

This provides a sharp contrast with the British Caribbean territories. Across the border from the Mexican Yucatan province, in British Honduras there was only one theatre in 1928 for a population of 65,000 . In other British territories the ratio was only slightly better. In Barbados by the early 1940s

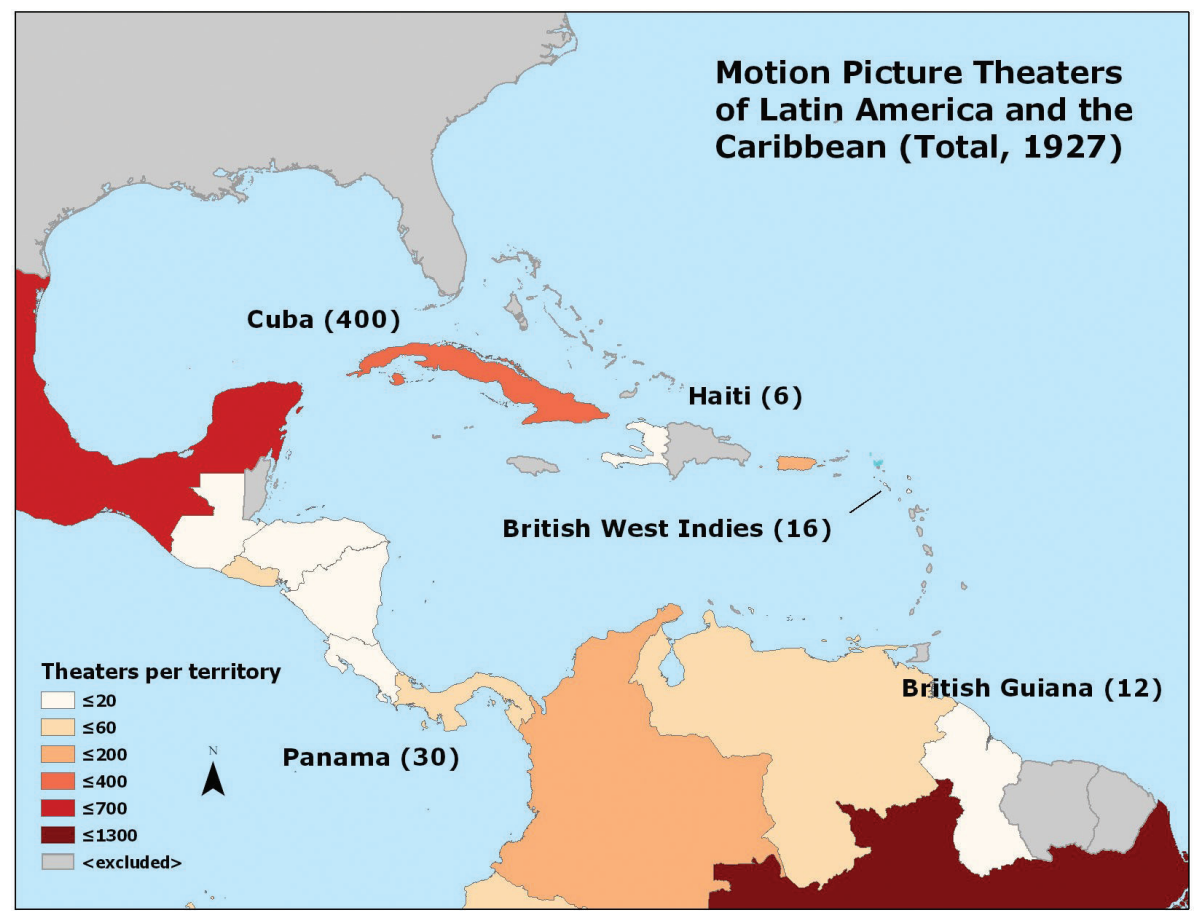

Figure 7. Map by the author. 


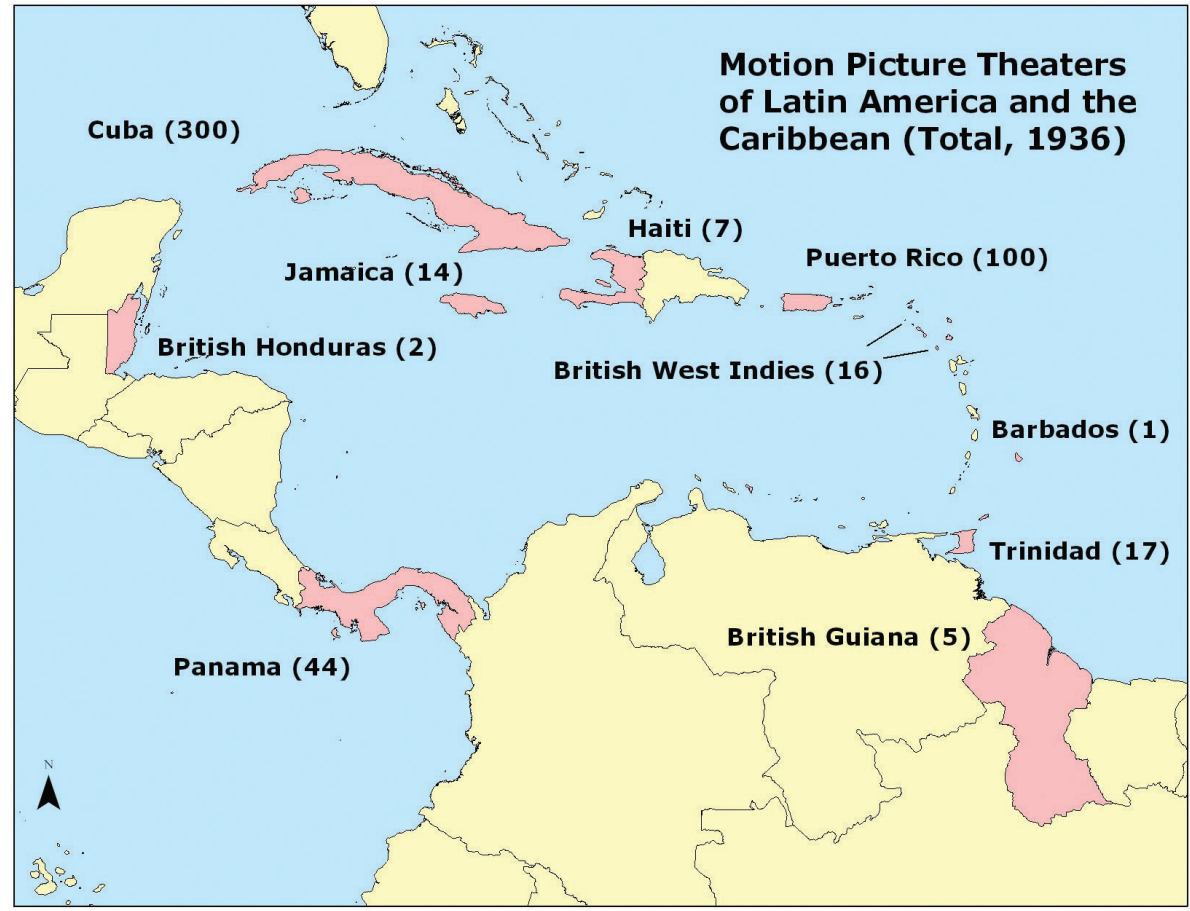

Figure 8. Map by the author.

there was one theatre per 48,000 people, and Jamaica 1 per 70,000. The ratios were somewhat better in Trinidad, which had one cinema per 18,000 people in 1945, and Guiana, where the ratio was one per $16,000 .{ }^{51}$ But these ratios had been dramatically improved in the later 1930s and early 1940 s by the advent of new cinemas for the South Asian immigrants in rural areas of these two colonies.

But there is more research to be done before the BWI can be usefully employed in comparative studies. As is the case in many world regions there is confusion in the available sources as to what precisely constitutes a cinema. Like many tropical regions, early screenings in the BWI were often held in outdoor venues which operated as the elements permitted. ${ }^{52}$ In colonial cities this confusion is further complicated by the tendency of European communities to create private segregated venues. Since colonies of the BWI could not legally segregate public facilities, private concerns which could restrict admission often functioned as cinemas. Thus in a colony such as Bermuda, there were two commercial theatres, but a half dozen other places in 1928 that were selling cinema tickets on a regular basis. Identifying these venues is particularly challenging since in Britain's West Indian territories there was no legal requirement for registering venues as cinemas. ${ }^{53}$ Thus many places where audiences regularly saw movies do not appear in consular reports or Hollywood periodicals. 
It is likely these kinds of ambiguities which account for discrepancies found in different sources that counted the numbers of venues in the BWI. For example in both 1927 and 1928 the Film Daily Year Book listed the 'British West Indies' as having 18 total cinemas for the entirety of the territories. Yet in the same year the British Colonial Office conducted a survey of the region which required the governor of each colony to submit a report on the number of venues, ownership of the cinema businesses, and volume of films distributed. This report identified 49 cinemas in the region. ${ }^{54}$

The colonial governments themselves appear to have had limited knowledge of the workings of the cinema industries within their own borders. For example in Trinidad the government was unsure in 1928 as to who actually ran the British Colonial Film Exchange, reporting to London that

although the Company operating the Empire, London, Olympic and Arima Theatres is registered as a British Company, it has been reported in the local press and it is generally understood that these theatres have been purchased by an American Syndicate, and that the Colonial Film Exchange Limited is merely the Agent of the Syndicate. ${ }^{55}$

Whether these discrepancies are the result of careless bookkeeping or ambiguities about the function of public leisure spaces, they will have to be clarified in order for future comparative work to be undertaken. ${ }^{56}$

In conclusion, this brief survey of the early history of the cinema in the BWI suggests that more research will need to be done before it can be usefully compared to other regions. But it is a worthwhile undertaking, because the cinema history of the British West Indies is well worth understanding. On a per capita basis, the number of cinemas in the BWI before the Second World War was miniscule compared to Europe and North America. But the cinema had a remarkable influence in the BWI. In the post-war era, its artists and intellectuals punched well above their weight in their contribution to global media and entertainment, and cinema infused their art. The Anglophone Caribbean produced a remarkable number of global artists in the twentieth century whose work was shaped by the cinema. Authors such as C.L.R James, V.S. Naipaul, and Marcus Garvey wrote about the impact of cinema on Caribbean identity, and the diverse forms of popular music such as ska, reggae, and calypso that emerged from the region were all informed by the experience of the cinema. Thus a careful and thorough reconstruction of the region's cinema history will provide broader insights into the relationship between cinema and the production of global popular culture in the twentieth century. 


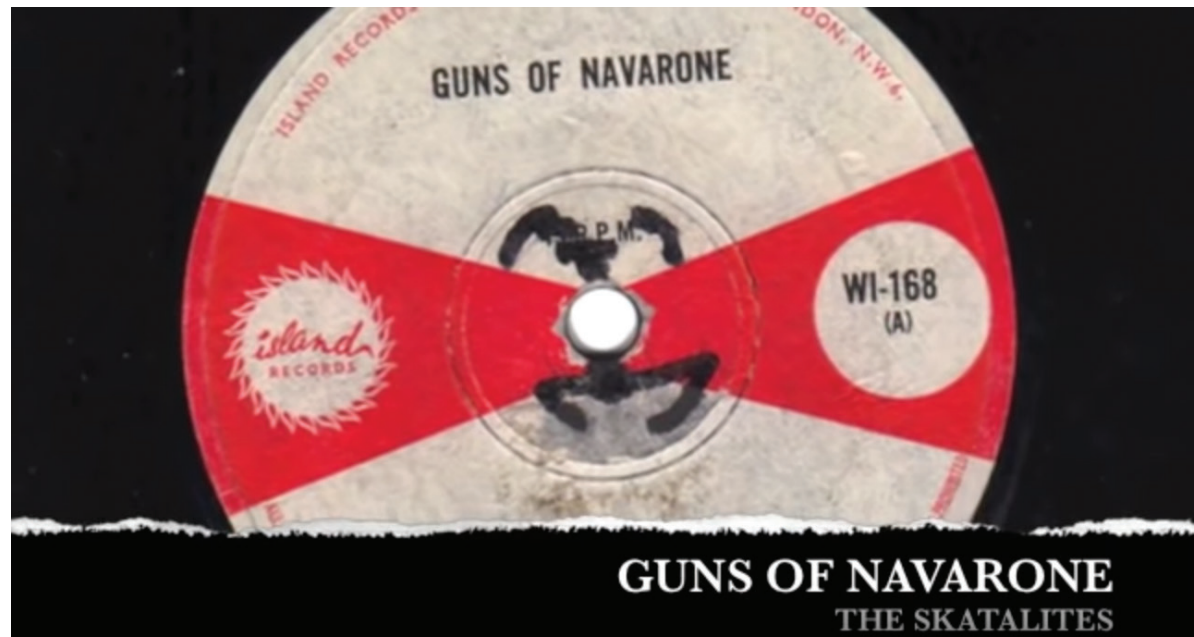

Figure 9. The Skatalites, 'Guns Of Navarone' (released 1965). This single vividly reflects the relationship between cinema and popular music in the Caribbean.

\section{Notes}

1 See Daniël Biltereyst and Philippe Meers, 'New Cinema History and the Comparative Mode: Reflections on Comparing Historical Cinema Cultures,' Alphaville: Journal of Film and Screen Media 11 (Summer 2016): 13-32, p. 13.

2 Biltereyst and Meers, 'New Cinema History'.

3 Ibid.

4 Daniël Biltereyst, Thunnis Van Oort and Philippe Meers 'Comparing Historical Cinema Cultures: Reflections on New Cinema History and Comparison with a Cross-National Case study on Antwerp and Rotterdam' in The Routledge Companion to New Cinema History, ed. Daniel Biltereyst, Richard Maltby and Philippe Meers (New York: Routledge 2019), 96-111.

5 This is an expansive use of the term, which includes the island nations as well as the mainland territories of British Guiana (now Guyana) and British Honduras (now Belize).

6 On the Ireland Bros. career in North America see Charles Musser and Carole Nelson, High-Class Moving Pictures: Lyman H. Howe and the Forgotten Era of Traveling (Princeton: Princeton University Press, 2016), 124.

7 The first recorded show in the BWI was reported in Kingston Jamaica, “Theatre Royal Announces Debut of 'Cinematograph',” The Gleaner, November 1, 1897, 2. This venue was destroyed in a devastating earthquake in 1907. 
8 The Ireland Bros. travels can be plotted through local newspapers. See for example the article "Pictures gone” in the Jamaica Gleaner, December 6, 1906, 8, on their ensuing tour of South America, or the Panama Star and Herald, January 1, 1907, 3, on their visit there. Several other itinerant film shows appear in the pages of these papers, such as the New Brunswick Film Company (Port of Spain Gazette, January 25, 1908, 7) and the Hamilton Cinematograph Company (Port of Spain Gazette, June 12, 1909, 10). But none appeared as frequently as the Ireland Bros.

9 See ad for The London Electric Theatre in the Port of Spain Gazette, January 31, 1911, 5.

10 Jamaica Chronicle, September 21, 1914.

11 For more on Roser's fascinating career see my conference paper “Our Genial Barnum: Captain A.J. Roser and the Limits of Imperial Re-Invention, » presented at the British Scholar Society’s Britain and the World Conference, June 2016.

12 Eric Rosenthal “The Foschini Group Story,” South African Jewry (1976), 370-373.

13 “Moving Pictures” The Gleaner, October 18, 1913, 3.

14 “Reply to Capt. Roser” The Gleaner, November 27, 1914, 14.

15 See "A Recent Fire" in The Gleaner, October 30, 1915, 6.

16 Michael Anthony, First in Trinidad (Port of Spain: Paria Publishing, 2004), 173.

17 Anthony, First in Trinidad.

18 Trinidad Guardian, August 29, 1918.

19 “Big Lawsuit Now Pending,” The Gleaner, August 14, 1919, 4.

20 Trinidad and Tobago Yearbook (1925), 65.

21 Daily Chronicle, January 4, 1917.

22 “Running a Summer Show All Year,” Exhibitor's Trade Review, May 31, 1924, 4.

23 See population figures published at http://www.populstat.info/populhome.html, accessed September 1, 2019.

24 The Jamaican papers covered several lawsuits by the Palace Amusement company against their many potential rivals.

25 R.P. Lamont, Small Island Markets for American Motion Pictures (U.S. Department of Commerce, U.S. Government Printing Office, 1931), 8.

26 “British West Indies," Exhibitor’s Herald-World, November 21, 1929, 69.

27 For an overview of Morais' litigation see James Burns, Cinema and Society in the British Empire, 1895-1940 (London: Palgrave/Macmillan, 2013), chapter 2. 
Ranjit Kumar, Thoughts and Memories of Ranjit Kumar (Trinidad: inPrint Caribbean limited, 1981), 12.

29 See "The Memoirs of Bruce Watson", 97 for a description of the popularity of Indian films in Guiana in the late 1930s. Published online at http://sites.rootsweb.com/ nyggbs/RogerAustin/ TheMemoirsofBruceWatson.pdf. Accessed September 1, 2019.

30 The Colonial Film Exchange tried to block MGM's entry into the market in court. See "Battle for the Films in Trinidad," The Gleaner, June 20, 1932, 23.

31 See Thelma Gutsche, The History and Social Significance of the Cinema in South Africa, 1895-1940 (Cape Town: Timmins, 1972). For their efforts in South Africa during the early 1930s see p. 213.

32 Morris Cargill, Jamaica Farewell (Secaucas: Lyle Stewart, 1978), 99.

33 Cargill, Jamaica Farewell , 104.

34 “The Majestic,” The Gleaner, December 15, 1939, 6.

35 The Gleaner, June 24, 1940, 11.

36 The Gleaner, December 21, 1940, 36.

37 The Gleaner, April 10, 1935.

38 Keith Q. Warner, On Location: Cinema and Film in the Anglophone Caribbean (London and Oxford: MacMillan Education, 2000), 6.

39 “The Movies," The Gleaner, March 2, 1941.

40 Harvey Neptune, Caliban and the Yankees: Trinidad and the United States Occupation (Chapel Hill: University of North Carolina Press, 2007), 68.

41 See Neptune, Caliban and the Yankees on the terms of the American occupation in the Caribbean territories.

42 Ibid., 9.

43 Lynne Macedo, The Impact of Indian Films in Trinidad, 2, The Society for Caribbean Studies Annual Conference papers 3 (2002), published online at http://www.caribbeanstudies.org.uk/papers/2002/olv3p10.PDF, accessed June 2, 2012.

44 For a discussion of censorship in the BWI during the 1930s see Burns Cinema and Society, chapter 2.

45 National Archives of the United Kingdom Colonial Office (CO), record CO/323/848, Reaction of Trinidad audiences to VD film 1920, letter Letitia D. Fairfield, Educational Commissioner.

46 CO 323/1073, Films Censorship. Cinematograph Film in British Guiana. Memorandum by W.E. Bradburn, Inspector general of police and chairman, cinematograph film censorship committee. 
47 See CO 323/1122/3. Colonial films committee recommendations: Replies from Colonial governments to circular, 1931.

Laura Fair Reel Pleasures: Cinema Audiences and Entrepreneurs in $20^{\text {th }}$ Century Urban Tanzania (Athens, Ohio: University Press, 2018).

49 See for example Lamont, Small Island Markets, or "Annual Survey of Motion-Picture Industry in Jamaica” (Industrial Reference Service: U.S. Department of Commerce, Washington D.C., February 4, 1941).

50 For the popularity of the early cinema in the Yucatan see Laura Isabel Serna, "Revista del Cinema: Silent Cinema in Yucatán," Film History 29, no. 1, Mexican Silent Cinema (Spring 2017): 1-29.

51 The ratios cited here for population and number of cinemas are based on population data from http:// www.populstat.info/populhome.html, accessed October 1, 2018, and the annual cinema lists published in the Film Daily Year Book.

52 This is an issue common to cinema studies in tropical climates, where open air and mobile cinemas were common. This is true in other Caribbean regions, as has been demonstrated in the study of Monterrey Cultura de la Pantalla en Monterrey (1895-1972), found at http://www.cinemacitycultures. com/cultura-de-la-pantalla-en-monterrey.html, accessed October 1, 2019.

53 CO 323/977/1 Films: Confidential. Replies to circular dispatch of January 8, 1927; April 4, 1928 response from Governor of Bermuda 'I have to point out that while a list of licensed theatres was asked for, there is no local provision for the licensing of buildings for public entertainments and the return therefore shews the buildings actually used for cinematograph purposes.'

54 See CO 323/1122/3 Colonial films committee recommendations: Replies from Colonial governments to circular, 1931.

55 CO 323/977/1 Films: Confidential. Replies to circular dispatch of 8 Jan 1927. Reply from the Governor of Trinidad and Tobago, 29 February, 1928.

56 There has been a good deal written about Britain's response to the spread of the cinema in her tropical empire before 1940. Overall the Colonial Office tried to monitor the effect of movies on local audiences, while at the same time deferring to local authorities to police the medium as they saw fit. This led to a pronounced diversity of censorship laws obtaining throughout the empire and commonwealth. See Burns, Cinema and Society, passim. 
TMG 23 (1/2) 2020

James M. Burns

\section{Biography}

James Burns teaches African History at Clemson University. He is the author several books, including Flickering Shadows: Cinema and Identity in Colonial Zimbabwe (Ohio University Press 2002), Cinema and Society in the British Empire (Palgrave 2013) and The Cambridge History of Sub-Saharan Africa (Cambridge: 2nd edition 2013). 


\section{TMG Journal for Media History}

Volume 23 No (1/2)/2020

DOI

https://doi.org/10.18146/tmg.585

\section{PUBLISHER}

Netherlands Institute for Sound and Vision

\section{COPYRIGHT}

Each article is copyrighted (c) by its author(s) and is published under license from the author(s). When a paper is accepted for publication, authors will be requested to agree with the Creative Commons Attribution 4.0 International License. 